\title{
PHRASEOLOGY DISCOURSE IN AIR TRAFFIC CONTROLLER'S COMMUNICATION
}

\author{
Khairunnisa Batubara \\ Fakultas Ilmu Budaya, Program Studi Doktor Linguistik, Universitas Sumatera \\ Utara, Indonesia \\ ichakhaibara@gmail.com
}

\begin{abstract}
This writing deals with the types of phraseology in air traffic controller's communication. The objective of this writing is to find out the types of phraseology used in communication between ATC of KNIA and pilot. The source of this writing is an air traffic controller of KNIA. The data of this writing are the communication between controller and pilot which spoken in statements or commands called phraseology (words and phrases). Descriptive qualitative method is applied as a qualitative design in conducting this research. The instrument of data collection is voice recorder to record the data.
\end{abstract}

Keywords: phraseology, air traffic controller, communication

\section{INTRODUCTION}

Discourse in the sense of human discourse is an umbrella term that covers a large spectrum of phenomena, in which there reside various kinds of discourse that are commonly pointed to in expressions such as 'legal discourse' (Danet, 1985), 'historical discourse (Struever, 1985), 'political discourse' (Seidel, 1985), 'Islamic discourse' (Puteh, 2000), 'academic discourse' (Stokoe, 1998), 'parent-child discourse' (Ervin-Tripp \& Strage, 1985), 'classroom discourse' (Sinclair \& Couthard, 1975), and a lot more. However, one may still wonder what the term 'discourse' itself really means in the first place. This is one of the questions that may come to one's mind when we talk about discourse phenomena. One of discourse phenomena will be discussed is about phraseology in aviation which is used by controller and pilot as their official language in the workplace.

Phraseology is the branch of linguistics; it refers to the language used by air traffic controller (ATC) in communication with pilot as the functions of conveying the meaning in language use. The language used by ATC which is called as phraseology become the reason in writing this scientific article. The reason shows that phraseology is not only the words or phrases spoken by everyone but phraseology is a language as a means of communication between controllers and pilot which had been standardized and also had certain meaning in conveying the statements or another speech functions (such commands, offers, or questions).

Cowie (2001) stated that in linguistics, phraseology is the study of set or fixed expressions, such as idioms, phrasal verbs, and other types of multi-word lexical units (often collectively referred to as phrasemes), in which the component parts of the expression take on a meaning more specific than or otherwise not predictable from the sum of their meanings when used independently. Phraseology also can be stated as loosely defined as the study of structure, meaning, and use of 
word combinations. As word combinations come in many different shapes and forms, the scope of the field is a function of the criteria used by linguists to distinguish phraseological units from non - phraseological ones. It means that phraseology is phrases or words which have the function in building a new phraseological unit to use as a means of language and it is different with English regularly used in general.

Language is a means of communication. Montgomery (2008) commented that language informs the way of people think, experience, and interact with each other. Language can be learned as a system of communication. Systematic knowledge about language and practical awareness of how it works is fundamental to the process of building mature communities. In field of aviation, the language exactly used by pilots, air traffic controllers, and other personnel associated with the aviation industry. Although the term may encompass a wide variety of language used in every situation, including the language of airlines mechanics, flight attendants, or ground service personnel, most research and teaching focus on the more specialized communication between pilots and air traffic controllers, often called radiotelephony.

In this writing, phraseology is used as a means of communication between controllers and pilot. This communication is absolutely different with common speech in daily life. In phraseology there are words and phrases which have certain meaning that had been standardized so that among controllers and pilot should have their own understanding in doing communication. From those all phenomenon and evidence, this writing is focused in finding the types of phraseology used in communication between ATC and pilots.

There are some previous relevant studies related to this topic which has been conducted by previous writers in the area of phraseology as the communication between air traffic controllers and pilot that obviously refers to aviation field. Those previous studies, which has been observed and carried out by other writers, actually had the different problems with this writing that will be conducted. These relevant studies may explore the writer's point of view in conducting this writing. The previous studies are represented as follow.

Stephanie Lopez and her colleagues: Anne Condamines, AmelieJosselin - Leray, Mike O'Donoghue, and Rupert Salmon, in a Journal of Air Transport Studies (2013) entitled Linguistic Analysis of English Phraseology and Plain Language in AirGround Communications, aimed to describe the different uses of English phraseology and plain language within pilot-controller (or air-ground) communications via a comparative study between two collections of texts (corpora): one representing the prescribed norm and made up of examples of English from two phraseology manuals; the other consisting of the orthographic transcription of recordings of real airground communications. The comparative study is conducted at a lexical level. It focuses on the discrepancies observed in the distribution of the corpora lexicon. Our preliminary results indicate that, in real air-ground communications, pilots and controllers tend to use more "subjectivity" markers (pronouns, courtesy expressions) than prescribed by the linguistic norm. This observation reflects their needs to use the language in its social role. A description of the 
$\begin{array}{lcr}\text { different } & \text { markers } & \text { introducing } \\ \text { subjectivity } & \text { in } & \text { air-ground }\end{array}$ communication can help understand the use of a more natural language in radiotelephony. In the long run, the results from the comparative study can be used to improve English radiotelephony teaching. This study supported the researcher in focusing what phraseology is and how different it is with general English.

Kitty Campbell Laird, in her research, An Analysis of Aviation Communications, Aviation English, and Methodology stated that her study will address the research methodologies which have been used in analyzing aviation English and communications. She will address the relevant taxonomies and coding schemes implemented and propose possible applications for her research. She reviewed some theories in the research of aviation communication and then made the conclusion of all she had got from elaborating and differentiating the theories. This reason gave the idea to the researcher about the communication between controllers as the user of phraseology and pilots as the user of plain language.

Gideon Ewers (2013) in his research entitled The Safety and Technical Journal of IFALPA said that non-standard phraseology may result in communication, traffic conflicts, and accidents. The scope of the study was communication and the use of nonstandard phraseology between pilots and controllers during all phases of flight. Surveys were designed to identify areas where established or local phraseology has been, or has the potential to be, misunderstood. (The use of aviation English was explicitly excluded from the report as this issue has been managed through other venues). In this research, the researcher also found the non - standard phraseology used in controller's communication.

Based on previous studies, this writing is conducted in focusing the types of phraseology which is not wellknown by everyone. By doing this writing, it will be shown how the phraseology used as the language in the communication between ATC and pilot.

$$
\text { In Federal Aviation }
$$

Administration (FAA 7110.65 2-1-1) Air traffic control (ATC) is a service provided by ground - based controllers who direct aircraft on the ground and through controlled airspace and can provide advisory services to aircraft in non-controlled airspace. The primary purpose of ATC worldwide is to prevent collisions, organize and expedite the flow of traffic, and provide information and other support for pilots. In some countries, ATC plays a security or defensive role, or it is operated by the military. The job of an Air Traffic Controllers is unique and demanding for it requires parallel thinking and rapid decision making. Each controller will be trained by the department using practical and simulation methods in acquiring the necessary skills.

Aguado de Cea (2007) stated that phraseology is the linguistic discipline that deals with the combination of words or the set of phraseological units or phrasemes of a certain specialized language. It means that phraseology defines as a group of phrase which combines word to word in building one meaning and become a new certain phrase. While Sinclair (1991) and Partington (2004) commented that phraseology has become a major area of interest in corpus linguistics. Philips (1991) also explored how official phraseology of air traffic communications differed from natural English. 
Based on some literature reviews, phraseology can be concluded commonly as a group of words which build a new meaning and it can be called as a phrase. In other words, phraseology means words and phrases as they are used in speech or writing to convey a specific meaning. In line with aviation field, phraseology becomes a main language in communication between Air Traffic Controllers (ATC) and pilots and it uses English as the natural language in phraseology itself.

In Document 4444 of ICAO, there are six types of phraseology used by ATC:

1. General Phraseology (GP) which used in general situations, wherever the operation of flight is running. Example $\langle$ CONTACT $>, \quad\langle$ CONFIRM $>$, etc.

2. Aerodrome Control Phraseology (AeroCP) used in the airport surroundings. Example CLEARED TO LAND, CLEARED TO TAKE OFF.

3. Approach Control Phraseology (AppCP) used when flight operation is closer to the airport area. It is expected to use a navigation system such as ILS (Instrument Landing System), VOR (Very high Omni Range), and NDB (Non Directional Beacon) to getting closer even leaving out the airport.

4. Area Control Phraseology (AreaCP) which used in the area where the aircraft has been close or reached the certain position in airspace (cruising level). It is commonly more than $25000 \mathrm{ft}$. which called as flight level 250, shortened as FL 250.

5. Radar Control Phraseology (RCP) which used by using radar. This radar assists controllers to getting down the aircraft for landing, avoiding accident, and in the right way. The tools are used in Area Control Center (ACC) and also Approach Control Office (APP). Almost airport in the world use this facility and commonly international airport.

6. Coordination Phraseology used by ground to ground station to coordinate the responsibility of air traffic controllers from one unit to another. Example of coordination among ACC and APP, APP and ADC (Aerodrome Control Tower), ACC and FSO (Flight Service Officer).

At times controllers will ask pilots to verify that they are at a particular altitude. The phraseology used will be: "VERIFY AT (altitude)." In climbing or descending situations, controllers may ask pilots to "VERIFY ASSIGNED ALTITUDE AS (altitude)." Pilots should confirm that they are at the altitude stated by the controller or that the assigned altitude is correct as stated. If this is not the case, they should inform the controller of the actual altitude being maintained or the different assigned altitude.

Communication explicitly as the unity of information, message, and understanding. Communication is the activity of conveying meaning through a shared system of signs and semiotic rules. In other words communications is a means of sending and receiving messages, orders, or another, including telephone, telegraph, television, and even radio. Communication involves the imparting or interchanging thoughts, opinions, or information among people by speech, writing, or signs. People communicate in different ways. 
The communication in air traffic controllers used utterances which spoken as the information of each other (controller and pilot) and it is called phraseology as a means of the communication. In this writing, the model of communication used by ATC and pilot is two - way communication. The two - way communication which always includes feedback from the receiver to the sender and lets the sender know the message has been received accurately. Two - way communication is a form of transmission in which both parties involved transmit information. Two - way communication has also been referred to as interpersonal communication. By applying two - way communication models, sender and receiver could be controller or even pilot. Because in this communication there is no specific rule to make that a controller should send the information or a pilot should be the receiver whereas a pilot also can be a sender of the information. In this research messages and feedback derive from the phraseology which is phrases and even words used in the communication interaction.

\section{METHOD}

This writing is conducted by applying a descriptive qualitative method. The source of data derived from the interaction between controllers (ATC) and pilots. The communication interaction deals with the statements or commands, such as phrases and words. The techniques of data collection used a descriptive technique. The descriptive techniques deal with the following aspects.

Observation: actually, observation is the main method in collecting the data based on qualitative principles, then interviewing ATC as the source of the data in the phraseology ATC itself with pilots. The phenomenon is observed as deep as possible based on reality. The observation in this writing is participant observation, the researcher had been all together with the subjects and it is conducted directly to ATC and pilot. While observing, the data are recorded when the communication occurred between controller and pilot. By this activity, the raw data are collected to be analyzed then. The data are limited because the communication is taken by using a radar controlling monitor and it is random because there are several controllers and pilots interact each other, it means a controller could control more than one pilot or a pilot could be controlled by more than a controller. So that's why the data are collected in one time and it could be a complete interaction or might be a single statement or command.

Interview: in this study, some questions are prepared to interview the subject (ATC) about his activity and the communication based on the problems of this research. Interviewing is done to get the natural and accurate data from the subjects. From this action, controller gives the direct explanation about the phraseology as he used in communication with pilot.

In analyzing data, interactive model by Miles and Huberman is applied. According to Miles and Huberman (2014), there are three steps of data analysis:

1. Data reduction: the process of identification. In this writing, data reduction includes:

a. Selecting: after recording the data in the step of observation, then the data are listened up deeply and carefully to get the clear communication between controller and pilot, recorded by a voice recorder, while listening to, the data are transcribed then selected 
based on the complete statements or commands spoken by controller or pilot and belong to the types of phraseology. This step is done repeatedly to get the final data.

b. Focusing and categorizing: in this step, the data focused on the types of phraseology. The selected data then

2. Data display: in this step, the data which has been selected, focused, categorized, and transformed are displayed descriptively, the data should be elaborated, and at last completely by using table as the fact and the real result of the data analysis. categorizing based on the types of phraseology needed in this research.

c. Transforming: the data actually the statements or commands interacted by controllers and pilot. So that's why, all data in this research should be transformed into words, no numbers or symbol. That's phraseology.
3. Drawing conclusion: in this step, based on the types of phraseology the explanation about how phraseology used in communication between controllers and pilot are described in detail by exemplifying the realizations types of phraseology.

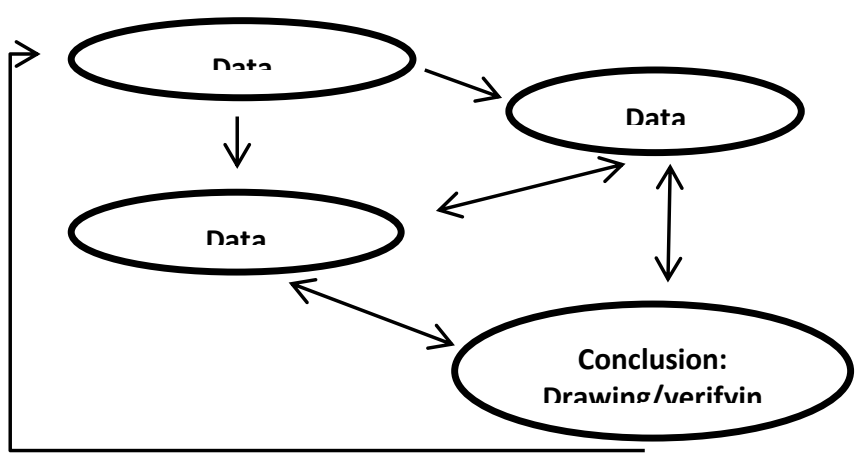

\section{RESULTS}

In this writing, the step of collecting data begins with recording the communication between controller and pilot by using a voice recorder (of mobile phone). The collected data is random because the voice recorder synchronized with a radar controlling monitor and the communication among controllers and pilot was running as long as possible with the given time while observing the situation of controlling room. The analysis of the data begins with listening out carefully to get the clear data. The data is listened repeatedly to get the maximal result. First there are sixty three statements or commands got from the recordings. Then it is listened up again to reduce the data based on the types of phraseology and there are fifty five statements got from this activity. After that, to make the analysis deeper than previous, the recording of the data is listened up again to reduce unclear statements or commands based on the types of phraseology and finally there 
are fifty statements or commands got completely and clearly based on the types of phraseology. After that the data which has been reduced then focused and categorized based on the types of phraseology and transformed all into words, by using the types of phraseology the patterns should be transformed in elaborating the research problem. The data analysis can be seen as follows:
JURNAL PENDIDIKAN BAHASA DAN SASTRA

The Types of Phraseology Used in Communication between ATC and Pilots

General Phraseology (GP) used in general situations, wherever the operation of flight is running. First, there was "responding in communication" found in General Phraseology. In this part, words or phrases have their each meaning in communication between ATC and pilot. It used to make some commands

\begin{tabular}{|c|c|c|c|}
\hline Selamat sore & $\begin{array}{c}\text { Indonesia one nine nine } \\
\text { three }\end{array}$ & Go ahead & Sir \\
\hline $\begin{array}{c}\text { Non - standard } \\
\text { phraseology }\end{array}$ & Aircraft identification & $\begin{array}{c}\text { Responding in } \\
\text { communication }\end{array}$ & $\begin{array}{c}\text { Non - standard } \\
\text { phraseology }\end{array}$ \\
\cline { 2 - 3 } & AreaCP & GP & . \\
\hline
\end{tabular}

\section{C : $\quad$ Selamat sore Indonesia one nine nine three go ahead sir}

\begin{tabular}{|c|c|c|c|}
\hline Indonesia one nine nine three & Confirm & Request & $\begin{array}{c}\text { Level three seven } \\
\text { three zero }\end{array}$ \\
\hline Aircraft identification & \multicolumn{2}{|c|}{$\begin{array}{c}\text { Responding in } \\
\text { communication }\end{array}$} & Flight level \\
\hline AreaCP & \multicolumn{2}{|c|}{ GP } \\
\hline
\end{tabular}

\section{$P: \quad \quad$ Indonesia one nine nine three confirm request level three seven three zero}

The statement means that ATC got to proceed the message from pilot. The controller said that the message will be continued and then pilot said what he means by giving a request that the aircraft should confirm the flight level. Thus in "responding in communication" there are only some words or phrases spoken by ATC to give commands to pilot.
Aerodrome is a defined area on land or water (including any buildings, installations and equipment) intended to be used either wholly or in part for the arrival, departure and surface movement of aircraft.ATC used this phraseology when the aircraft was ready to take - off or landing in the runway or taxi. It means, the situation is not in the air yet, it is still on the runway of the aircraft.

\begin{tabular}{|c|c|c|c|c|}
\hline Ok & Direct & Approved & Give way & $\begin{array}{c}\text { One eight three } \\
\text { for traffic }\end{array}$ \\
\hline $\begin{array}{c}\text { Non }- \\
\text { standard } \\
\text { phraseology }\end{array}$ & $\begin{array}{c}\text { Indicating } \\
\text { route }\end{array}$ & $\begin{array}{c}\text { Responding in } \\
\text { communication }\end{array}$ & $\begin{array}{c}\text { Taxi } \\
\text { procedure }\end{array}$ & $\begin{array}{c}\text { Location of traffic } \\
\text { (taxi procedure) }\end{array}$ \\
\cline { 2 - 5 } & GP & GP & AerodromeCP & AerodromeCP \\
\hline
\end{tabular}

\section{C: $\quad$ ok direct approved and give way one eight three for traffic}

From the data, this type of ATC was in the aerodrome controller or tower.
$\mathrm{He} / \mathrm{she}$ should control the situation of traffic before taking off and landing. So 
actually this phraseology used by Aerodrome Controller but sometimes in certain situation ATC in radar controller might use this phraseology. The statement means that the controller allowed the aircraft to come in and ready for traffic.

Approach Control Phraseology (App CP) is used when flight operation is closer to the airport area. It is expected to use a navigation system such as ILS (Instrument Landing System), VOR (Very high Omni Range), and NDB (Non Directional Beacon) to getting closer even leaving out the airport. The example can be seen:

\begin{tabular}{|c|c|}
\hline Indonesia one eight six & Two thousand five hundred feet \\
\hline Aircraft identification & Flight level \\
\hline AreaCP & GP \\
\hline
\end{tabular}

$P$ : $\quad$ Indonesia one eight six two thousand five hundred feet

\begin{tabular}{|c|c|}
\hline One eight six & Turn left heading two seven zero \\
\hline Name of unit & Approach control service \\
\hline AreaCP & AppCP \\
\hline
\end{tabular}

\section{$C: \quad$ one eight six turn left heading two seven zero}

The statement means that the aircraft should take turn straight to the left heading 270. It comes from the commands of the controller.
Area Control Phraseology (Area $\mathrm{CP})$ is used in the area where the aircraft has been close or reached the certain position in airspace (cruising level) which can be seen in the example below:

\begin{tabular}{|c|c|c|}
\hline Indonesia two seven one & Descend to & Three thousand feet \\
\hline Aircraft identification & Level adjustment / flight level \\
GP
\end{tabular}

\section{C: Indonesia two seven one descend to three thousand feet}

\begin{tabular}{|c|}
\hline Request \\
\hline Responding in communication \\
\hline GP \\
\hline
\end{tabular}

\section{$P: \quad$ request}

From the data above, ATC used Area Control Phraseology to inform about aircraft identification which is "Indonesia two seven one (GIA 271)". Aircraft identification can be found in Area Control Service.

$$
\text { Radar Control Phraseology }
$$

(RCP) is used by using radar. This radar assists controllers to getting down the aircraft for landing, avoiding accident, and in the right way. The tools are used in Area Control Center (ACC) and also Approach Control Office (APP). Almost airport in the world use this facility and commonly international airport. Radar controlis the term used to indicate that radar derived information which is employed directly in the provision of air traffic control service. In this 
phraseology, there was only general radar found in the communication. It can be seen in the example below:

\begin{tabular}{|c|c|}
\hline Turn left heading three zero two & Continue to six thousand \\
\hline Approach control service & General radar \\
\hline AppCP & RCP \\
\hline
\end{tabular}

\section{$C: \quad$ turn left heading three zero two}

\section{continue to six thousand}

From the data, ATC would like to tell the pilot that he should continue his flight to level six thousand.

The characteristic of non standard phraseology is only one, it cannot be found in the international phraseology commonly used as standardized phraseology. Non-standard phraseology may result in miscommunication, traffic conflicts, and accidents. Commonly ATC used mostly standard phraseology to communicate with pilot but sometimes in another case ATC used non-standard phraseology as long as it did not make some mistakes between them and could inform what he meant to the pilot.

\begin{tabular}{|c|c|c|c|}
\hline Stand by & Sir & Traffic number one & $\begin{array}{c}\text { Runway zero } \\
\text { five }\end{array}$ \\
\hline $\begin{array}{c}\text { Responding in } \\
\text { communication }\end{array}$ & $\begin{array}{c}\text { Non }- \text { standard } \\
\text { phraseology }\end{array}$ & Traffic information & $\begin{array}{c}\text { Aerodrome } \\
\text { information }\end{array}$ \\
\cline { 1 - 3 } GP & GP & AerodromeCP \\
\hline
\end{tabular}

C: $\quad$ stand by sir traffic number one runway zero five

"Sir" is non - standard phraseology. There is no word or phrase "sir" in standard phraseology. In fact, ATC could state "stand by, traffic number one runway zero five (stand by, traffic 1 runway 05)" but she might think if she used non - standard phraseology never been worried by pilot, it should be fine to communicate each other.

Based on ICAO, there are six types of phraseology as standard phraseology. But in this writing, for the types of phraseology used by controllers, it is found as only five types of phraseology; general phraseology, area control phraseology, radar control phraseology, approach control phraseology, and aerodrome control phraseology, as the standard phraseology, and also non - standard phraseology. In this writing, the specific subject or controller is on radar control, and the focus of this controller is to control the airspace while the aircraft is on the air and they interact with pilots.

Actually, each type of phraseology has its function in deriving the information, especially general phraseology, it can be used in all situation and condition. In this writing, the data are recorded in radar control room where the controller focused on radar control phraseology. It means that a controller handled the airspace communication that the aircraft is being controlled while in the air. In Indonesia, there are only several airports have radar in controlling the aircraft such as Kuala Namu International Airport. In radar room, actually the controllers not only use radar control phraseology as their means of communication, but they also use general phraseology, area control 
phraseology, aerodrome control phraseology, and approach control phraseology in making communication with pilot. That's why in this writing, there are found only five types of phraseology used in communication between controller and pilot and there is not found coordination phraseology because it is used by ground to ground station to coordinate the responsibility of air traffic controllers from one unit to another, such as coordination among ACC and APP, APP and ADC (Aerodrome Control Tower), ACC and FSO (Flight Service Officer).

\section{DISCUSSION}

Although this writing is aimed at enriching the theories of phraseology especially the use of language of Air Traffic Controller, the phraseology used in communication, the types of phraseology used in communication between ATC and pilot, moreover the writer expects there will be another research who interests in doing the next research about this study as the expand of this study and creates another phenomenon.

Phraseology is a unique language use in aviation. However everyone sometimes does not get any understandings about that. Moreover, this writing hopefully can give a contribution to all readers, even this is only in the academic surroundings, but an educated one who has understood can give the explanation about how phraseology exist in a language as a unique and special language including in English.

As the results of this writing are aimed at contributing the information about language used of Air Traffic Controller (ATC) as the process of communication by using phraseology for students, lecturers, and those who are interested in this field, however this research can be useful for everyone who has ideas in enriching this research especially the use of English for specific purposes.

\section{CONCLUSION}

There are five types of phraseology used by ATC in communication with pilot in this scientific writing; they are General Phraseology (GP), Area Control Phraseology (Area CP), Aerodrome Control Phraseology (Aerodrome CP), Radar Control Phraseology (RCP), Approach Control Phraseology (App $\mathrm{CP})$ as standard phraseology, and even non - standard phraseology.

Phraseology used by ATC is commonly used standard phraseology which has been standardized by ICAO. ATC might combine the types of phraseology based on the condition and situation needed. In another case and situation, ATC sometimes used non standard phraseology in communication with pilot. Thus, between ATC and pilot, there is no worries occur when they communicate each other as long as they can get the point what they mean. It is possible that one time the non - standard phraseology can be the regular phraseology used in controller's communication whether the words or phrases will be standardized by ICAO or not.

\section{REFERENCES}

Aguado de Cea, G. 2007. A Multiperspective Approach to Specialized Phraseology: Internet as a Reference Corpus for Phraseology. In S. Posteguillo, M.J. Esteve and M.L. Gea-Valor (eds.). The Texture of Internet: 
Netlinguistics in progress. Newcastle: Cambridge Scholars Publishing.

Annex 10. 1985. Aeronautical Telecommunication Annex 10 Vol. II. Montreal: ICAO

Bogdan, R. \& Biklen, S. 2007. Qualitative Research for Education. (5 $5^{\text {th }} E d$.). Boston: Allan and Bacon

Cowie, A.P. 2001. Phraseology: Theory, Analysis, and Applications. Oxford: Oxford University Press.

Granger, Sylviane \& Meunier, Fanny. 2008. Phraseology: An Interdisciplinary Perspective. John Benjamins Publishing Company, Amsterdam / Philadelphia

IFALPA Safety Bulletin 12SAB011, September 22, 2011. New ATC Phraseology During Runway Construction in US Airports.

International Civil Aviation Organization (ICAO). 2007. Manual of Radiotelephony: Fourth Edition. Approved by the Secretary General and published under his authority.

International Civil Aviation Organization (ICAO). 2010. 'Manual on the Implementation of ICAO Language Proficiency Requirements.' Doc 9835.AN/453, 2nd ed.Miles, M.B., and Huberman, A.M. 1984. Qualitative Data Analysis, 16. Newbury Park, CA: Sage.

Inter Pilot. 2013. The Safety and Technical Journal of IFALPA Vol. 1 No. 3. October 2013
Miles, M.B, and Huberman, A.M. 2014. Qualitative Data Analysis, 3rd Ed., p. 10-12. Newbury Park, CA: Sage

Montgomery, M. 2008. An Introduction to Language and Society. $3^{\text {rd }}$ ed. London, Routledge. 